to Nelson and Peltason at the Committee's annual reception.

Nelson and Peltason were recognized for their contributions to the political science discipline and their efforts to improve the status of black Americans. The committee began its awards program nine years ago to commend those who have advanced the interests of black political scientists and have distinguished themselves as scholars, teachers, or activists in civic affairs.

Michael Preston of the University of Southern California, chair of the Committee on the Status of Blacks, presided over the awards ceremony. Other members of the committee include: Woodrow Jones, Jr., San Diego State University; Roger Oden, Governors State University; Gary Orfield, University of Chicago; and Ernest Wilson, University of Michigan.

\section{APSA Annual Meeting Placement Service}

The Annual Meeting Placement Service in Washington could barely contain the pressure of job seekers and prospective employers. The 1988 Placement Service recorded an increase in the number of employers using the service, the number of job applicants, and most significantly, the number of positions available.

Table 1. Annual Meeting Placement Services, 1986, 1987, and 1988

\begin{tabular}{lll}
\hline 1986 & 1987 & 1988 \\
Washington & Chicago & Washington \\
\hline
\end{tabular}

127 Employers 143 Employers 161 Employers 487 Applicants 423 Applicants 545 Applicants 213 Positions 227 Positions 252 Positions 6 Various* 9 Various* 4 Various*

"Various refers to listings of more than one position at a single institution.

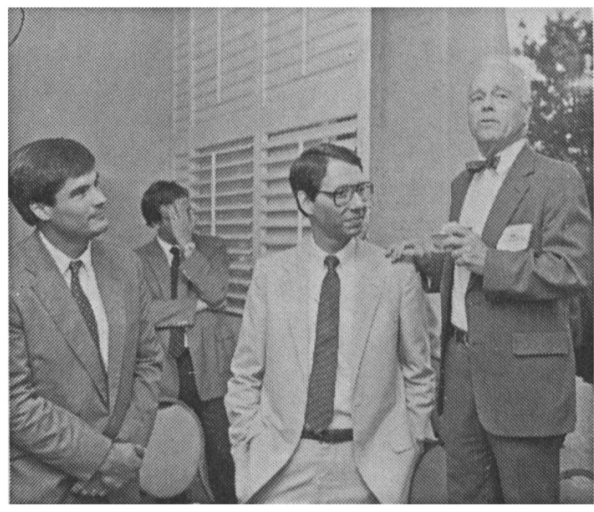

Friends and alumni of the University of Virginia's Department of Government and Foreign Affairs honor the retirement of Inis L. Claude.

\section{Recent LSS Activities Reviewed and Plans for 1988-89 Set}

At the Annual Business Meeting of the Legislative Studies Section of the American Political Science Association in Washington, DC, on September 2, 1988, Alan Abramovitz of Emory University was elected as Program Chairman of the Section for 1988-89. In this capacity, he will

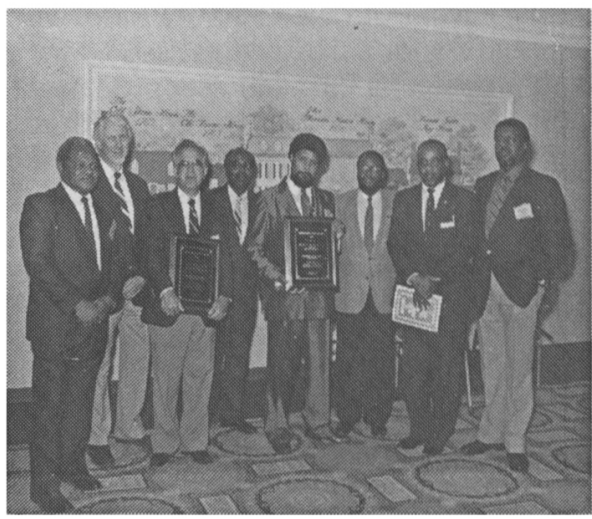

Committee on the Status of Blacks in the Profession honors Peltason and Nelson: I. to r., Michael Preston, Robert Salisbury, Jack W. Peltason, Lucius Barker, William E. Nelson, A. L. Stokes, Maurice Woodard and Mitchell Rice. 
organize both LSS and APSA Legislative Politics panels for the 1989 APSA meeting in Atlanta.

The Legislative Studies Section continues in 1988 to be led by L. Sandy Maisel of Colby College while Lawrence D. Longley of Lawrence University serves as Secretary-Treasurer and Editor of the LSS Newsletter. Melissa P. Collie of the University of Texas, Catherine E. Rudder of the American Political Science Association, and Glenn R. Parker of Florida State University, serve on the Section's Executive Board.

During 1987-88, the LSS provided extensive coverage of professional activities and information of interest to legislative scholars in issues of the LSS Newsletter which ran to a total of 300 pages for the year. The two regular issues of November and May contained a wealth of information concerning recent and forthcoming professional meetings, LSS activities, professional notes, book reviews, and mini professional articles in the "Extension of Remarks" section edited by Larry Dodd of the University of Colorado. This Newsletter section in 1987-88 included symposia of original professional research and scholarly analysis on "Congress and Public Policy" and "The United States Congress in Comparative Perspective."

The two regular Newsletter issues were supplemented by the 1988 LSS Membership Directory and Research Register. This guide was drawn from the LSS Data Base, which is regularly updated and revised to incorporate latest information supplied by LSS members concerning current addresses and legislative research interests. The 1988 Directory reported addresses and research interests as of April I, 1988, for a record 692 members of the Legislative Studies Section.

In 1987, the Legislative Studies Section launched a new LSS Book Series on Legislative Research to be published every two years by the University of Tennessee Press. Each volume in the series will contain 8 to 12 original studies of emerging or persistent questions in the study of legislative politics and behavior. Additional information concerning the LSS Book Series on Legislative Research is available from the
Series editor, Glenn R. Parker, Department of Political Science, The Florida State University, Tallahassee, FL 32306.

\section{Legislative Studies Section Gives CQ Press Award; Announces Prize Committee for 1989}

At a special awards ceremony held on September 1 in conjunction with the American Political Studies Association Annual Meeting in Washington, DC, the Legislative Studies Section of the APSA conferred the $1988 \mathrm{CQ}$ Press Award, and announced the $\mathrm{CQ}$ prize committee for 1989.

The CQ Press Award honors the outstanding paper in legislative politics presented at the year's preceding APSA Annual Meeting. The 1988 winners were John R. Hibbing of the University of Nebraska and John Alford of Rice University for their 1987 APSA paper "Responsiveness in the Senate." The prize was decided upon by an LSS Committee chaired by David Brady of Stanford University and including Keith E. Hamm of Texas A\&M University.

In their award winning paper, Hibbing and Alford argued that the central intended dynamic of the bicameral arrangement of the U.S. Congress is the interaction of an electorally sensitive House of Representatives with an electorally insular and more reflective Senate. Concerned that the lower house would prove to be "changeable, and susceptible to excess," the founders crafted an electoral arrangement that would shield the upper house as a necessary "defense to the people against their own temporary errors and delusions" (Federalist 63). Observers of the contemporary Senate see little evidence that the body is fulfilling this restraining role. The methods by which the founders sought to establish the distinctive nature of the two chambers were electoral, and the historical performance of those mech- 